\title{
Board of Directors' Interest in Share Ownership and Earnings Management
}

\author{
Philip Jehu*1, Mohammad Azhar Ibrahim ${ }^{2}$ \\ ${ }^{1}$ Department of Accounting and Business Administration, Federal University Kashere, Gombe, Nigeria. \\ 2 Tunku Puteri Intan Safinaz, School of Accountancy, Universiti Utara Malaysia.
}

\begin{abstract}
In this study, we examine the effect of directors' ownership on earnings management practices. Explicitly, we draw from the agency theory to distinguish between ownership by non-executive directors and ownership by executive directors to investigate reasons for directors and managerial opportunistic behaviour. Utilising data from a sample of 864-firm-year observations ranging from 2009 to 2017 period, we test our hypothesis through OLS regression. We find that non-executive directors' interests in shareholding are significantly associated with higher levels of earnings management. We observed a decrease in abnormal accruals on the overall basis of the combined ownership of both executive and non-executive directors. Overall, ownership by all directors combined significantly reduces managerial opportunism. By contrast, there is no evidence that executive directors' ownership mitigates managerial opportunism. This paper contributes to corporate governance literature, particularly when the independence of board members is essential. This study disaggregates board ownership into executive holdings and non-executive holdings, dimensions which were hitherto rendered as managerial ownership or board ownership. These findings imply firms' corporate governance policy and regulations.
\end{abstract}

Keywords: Earnings Management, Board of Directors, Ownership, Interest, Nigeria

JEL Classification: G30

Paper Type: Research

* Corresponding author: E-mail: jehuphilip@gmail.com, Phone: +2348100110704 


\section{INTRODUCTION}

Corporate boards are statutorily saddled with the responsibility of monitoring the quality of informational content of financial reports. Board monitoring is essential because managers often have conflicting interest with that of shareholders. This same board is composed of executive directors (managers) and to a more significant extent, non-executive directors (to demonstrate independence) who jointly take decisions that appertain financial reporting. Both categories of directors have rights to own shares in the firm, except for a third category within the non-executive directors who are designated explicitly as independent non-executive directors. ${ }^{1}$

The issue of corporate board members' interest in shareholding and its potential opportunism on earnings management continues to be a subject of interest in corporate governance discussion. Prior studies document that managerial ownership and directors' ownership affect the corporate board's opportunistic behaviour towards earnings. For example, Hooghiemstra, Hermes, Oxelheim, and Randøy (2019) assert that the board of directors is a critical mechanism to restrict managers' opportunistic behaviour. These studies have abundant evidence that earnings management stems out of ulterior motive and is counterproductive.

While the literature generally focuses on managerial ownership, there is little evidence examining the opportunism of independent and non-executive directors. In this study, we partition board-shareholding in two: managerial and non-executive, to investigate what ownership exerts the most effect on earnings management. We ran a regression analysis to examine the effect of director ownership on earnings management practices.

Our findings suggest that earnings management, as defined by abnormal accruals proxy, is significantly higher and is associated with non-executive directors' interests in shareholding. However, no evidence that executive directors' ownership mitigates managerial opportunism. These findings are consistent with the notion that if the board of directors have interest in shareholding, they will ensure quality reporting but inconsistent with the idea that managers (executive directors) do engage in earnings management if they are part owners.

Our paper contributes to knowledge by giving more insight into various categories of board members about their shareholdings, and how this might affect their opinions, judgments, and decisions to report earnings. Accounting and corporate governance literature are enhanced. This study might be of interest to corporate boards and policymakers.

The rest of this paper continues with literature review and hypotheses development in Section 2, research design in Section 3, the results in Section 4, and the conclusion in Section 5 .

\section{LITERATURE REVIEW AND HYPOTHESES DEVELOPMENT}

The agency theory posits that there is a disparity between firm ownership (stockholders) and firm control (managers) (Ran, Fang, Luo, \& Chan, 2015). According to Ujunwa, Okoyeuzu, and Nwakoby (2012), the agency theory suggests that where management and ownership are separate, managers tend to act in self-interest which may not necessarily be in the best interest of the shareholders. Hence, there is a need to monitor

\footnotetext{
${ }^{1}$ Non-executive directors or outside directors are usually put in place to demonstrate board independence as a requirement to fulfil corporate governance regulations. In Nigeria, it is further required to have at least one designated "independent nonexecutive director(s)" from among the non-executive directors. This informs the perceived lack of true independence of the non-executive directors.
} 
the activities of management. This need for board monitoring largely depends on the magnitude of the manager's interests' divergence from that of the shareholders (Peasnell, Pope, \& Young, 2005). It is expected that managerial shareholding should lead to a greater alignment of interests.

Proponents of board-shareholding argue that insider (directors) ownership is associated with higher earnings quality, thus significant in mitigating earnings management (Vafeas, 2005). Similarly, managerial ownership reduces the level of earnings management (Alves, 2012). Further, there is evidence that firms having low managerial ownership tend to engage in earnings management ( $\mathrm{O}^{\prime} \mathrm{Callaghan}$, Ashton, \& Hodgkinson, 2018). Again, Francis, Hasan, Park, and Wu (2015) pointed out that increase in separation between managerial ownership and control will likely lead to agency problem, hence affecting managers reporting incentives (Sharon, 2009).

Contrariwise, those who argue against this view argue that managerial ownership is related to lower earnings quality (Dechow, Ge, \& Schrand, 2010). To buttress this point of view, a study shows that the outside non-executive directors' ownership is associated with a higher quality of financial reporting (Klein, 2002). While managers are likely to manage earnings to avoid reporting losses, outside (non-executive) directors are more likely to reduce earnings (Peasnell et al., 2005).

Teshima and Shuto (2008) assumed that there are two types of motivations for managerial shareholding. First is that if managers own shares, they will work to enhance its value. Second, if managers expect re-appointment, they will try to impress shareholders. These incentives provide an opportunity for managers to present quality financial reports that are free from opportunism. Based on the preceding arguments, we hypothesized that:

$\mathrm{H}_{1}$ : Directors' interest in share ownership is negatively associated with earnings management

$\mathrm{H}_{2}$ : Non-executive directors' interest in share ownership is negatively associated with earnings management

$\mathrm{H}_{3}$ : Executive directors' interest in share ownership is negatively associated with earnings management.

\section{RESEARCH DESIGN}

\subsection{Data and Sample}

The sample is comprised of firms listed on the Nigerian Stock Exchange (NSE) as of 2017, excluding financial institutions because of its peculiar accounting and regulatory framework on corporate governance. Corporate governance data were extracted from listed firms' annual reports downloaded from the website of the NSE, covering 2009 to 2017 period. Financial data were obtained from Thomson Reuters Eikon database.

\subsection{Dependent Variable}

Many authors have used various earnings management models and proxies: abnormal (discretionary) accruals, fraud, misstatement, and so on. To analyse the relationship between the board of directors' interest in shareholding and earnings management, we utilised the accruals-based measure. The discretionary accruals are easier to manage but difficult to detect by investors. So, it offers the managers the opportunity to choose between methods that potentially favour the presentation of their performance even if it could turn otherwise. Consistent with extant accounting and corporate control literature, 
we utilise the abnormal accruals as earnings management proxy (Abbott, Daugherty, Parker, \& Peters, 2016; Hooghiemstra et al., 2019; Kothari, Leone, \& Wasley, 2005; Waweru \& Prot, 2018). This measure is the Kothari et al. (2005) performance-matched model. We employed this proxy because firm performance might be a key reason for boards decision when their interests are at stake.

$$
\frac{T A_{\mathrm{i} t}}{A_{\mathrm{i} t-1}}=\alpha_{1}+\alpha_{1}\left(\frac{1}{A_{\mathrm{it}-1}}\right)+\alpha^{2}\left[\left(\frac{\Delta R E V_{\mathrm{it} t}-\Delta R E C_{\mathrm{it}}}{A_{\mathrm{it} t-1}}\right)\right]+\alpha^{3}\left(\frac{P P E_{\mathrm{i} t}}{A_{\mathrm{i} t-1}}\right)+\alpha^{4}\left(\frac{R O A_{\mathrm{i} t}}{A_{\mathrm{it}-1}}\right)+\varepsilon_{\mathrm{i} t}
$$

where,

$$
\begin{array}{ll}
A_{i_{t}} & =\text { lagged total assets } \\
\triangle R E V_{i_{t}} & =\text { change in revenues in year } t \\
\triangle R E C_{i_{t}} & =\text { change in receivables in year } t \\
P P E_{i_{t}} & =\text { gross property, plant and equipment in year } t \\
R O A_{i_{t}} & =\text { return on assets in year } t \\
\varepsilon & =\text { error term. }
\end{array}
$$

\subsection{The Model}

This study utilises the regression in equation (2) to test whether corporate boardshareholding substantially constrain the incidence of earnings management.

$$
\begin{array}{r}
E M=\beta_{0}+\beta_{1} \text { DOWN }_{\mathrm{i} t}+\beta_{2} \text { NEDOWN }_{\mathrm{i} t}+\beta_{3} \mathrm{EDOWN}_{\mathrm{i} t}+\beta_{4} \mathrm{CTEN}_{\mathrm{i} t}+\beta_{5} \mathrm{BSIZE}_{\mathrm{i} t} \\
+\beta_{6} \mathrm{NEXD}_{\mathrm{i} t}+\beta_{7} \text { NLFSIZE }_{\mathrm{i} t}+\beta_{8} \mathrm{LEV}_{\mathrm{i} t}+\beta_{9} \mathrm{ROA}_{\mathrm{i} t}+\beta_{10} \mathrm{FAGE}_{\mathrm{i} t}+\varepsilon_{\mathrm{i} t}
\end{array}
$$

All the variables are as defined in Table 1.

\subsection{Explanatory Variables}

In Nigeria, corporate governance laws require a listed firm to disclose its ownership structure, and to disclose the shareholding interests of all the directors specifically. In some of the firms, directors' ownership could be quite substantial. As it is the responsibility of the directors to prepare financial statements, conflict of interest might set in subject to what class of director and the extent of shareholding. To analyse whether boardshareholding constrains accruals earnings management, we utilise three classes of ownership variables: all directors' ownership, non-executive directors' ownership and executive directors' ownership. DOWN is the proportion of shares owned by all the directors. NEDOWN is the fraction of shares owned by the non-executive directors. $E D O W N$ is the proportion of shares owned by the executive directors.

\subsection{Control variables}

As in other studies, we include a number of control variables that are associated with earnings management: CEO tenure (CTEN), board size (BSIZE), non-executive directors (NEXD), firm size (NLFSIZE), leverage (LEV), return on assets (ROA), and firm age (FAGE) (Tessema, Kim, \& Dandu, 2018; Waweru \& Prot, 2018). 


\subsection{Variable definitions}

Table 1. Variable measurements

\begin{tabular}{|c|c|c|}
\hline Variable name & Measurement & Source \\
\hline EM & The Kothari et al. (2005) measurement model & Waweru and Prot (2018) \\
\hline DOWN & The proportion of shares held by all directors & $\begin{array}{l}\text { Waweru and Prot (2018); } \\
\text { Teshima and Shuto (2008) }\end{array}$ \\
\hline NEDOWN & $\begin{array}{l}\text { The proportion of share ownership by non-executive } \\
\text { directors }\end{array}$ & Vafeas (2005) \\
\hline EDOWN & $\begin{array}{l}\text { The proportion of share ownership by executive } \\
\text { directors }\end{array}$ & Alzoubi (2014) \\
\hline CTEN & The number of years CEO was in office & Ebrahim (2007) \\
\hline BSIZE & The number of board members of a firm in a year & Alves (2012) \\
\hline NEXD & $\begin{array}{l}\text { The number of non-executive (outside) directors } \\
\text { scaled by board size }\end{array}$ & Waweru and Prot (2018) \\
\hline NLFSIZE & The natural log of total assets & Tessema et al. (2018) \\
\hline LEV & The ratio of total debt to total assets & Tessema et al. (2018) \\
\hline ROA & Profit or loss after tax divided by total assets & (O’Callaghan et al., 2018) \\
\hline FAGE & The number of years firm was incorporated & Tessema et al. (2018) \\
\hline
\end{tabular}

\section{RESULTS}

\subsection{Descriptive statistics}

Table 2 presents the summary statistics. Concerning the test variables, we notice that the mean value of all the directors' shareholding DOWN, is $21 \%$. The non-executive directors NEDOWN have a mean value of $11 \%$, and the executive directors have a mean value of $2 \%$. Overall, this suggests that directors on corporate boards in Nigeria have controlling interests in their firms' ownership.

Further, the average CEO, CTEN has been with the board for 5 years, indicating some lots of experience. The average board size BSIZE is 9 , with values that range from 4 to 15. Out of this, $70 \%$ of the sampled boards members are non-executive directors, which suggest higher board independence.

Table 2. Descriptive Statistics

\begin{tabular}{llllllll}
\hline Variable & $\mathbf{N}$ & Min & Max & Mean & SD & Skewness & Kurtosis \\
\hline EM & 864 & .0011 & .2520 & .0819 & .0421 & .2522 & 2.486 \\
DOWN & 864 & .0030 & .8000 & .2089 & .2302 & .9757 & 2.587 \\
NEDOWN & 864 & .0017 & .6435 & .1147 & .1100 & 1.485 & 5.414 \\
EDOWN & 864 & 0 & .1555 & .0195 & .0284 & 2.308 & 8.721 \\
CTEN & 864 & 1 & 16 & 4.609 & 2.981 & .9093 & 3.423 \\
BSIZE & 864 & 4 & 15 & 8.661 & 2.268 & .3157 & 2.584 \\
NEXD & 864 & .333 & .923 & .7042 & .1294 & -.4853 & 2.626 \\
NLFSIZE & 864 & 4.488 & 14.24 & 9.276 & 1.832 & .06056 & 2.649 \\
LEV & 864 & .0234 & .9803 & .5270 & .2046 & -.3054 & 2.601 \\
ROA & 864 & -.891 & .7927 & .1362 & .2363 & -.1625 & 3.983 \\
FAGE & 864 & 3 & 94 & 38.44 & 19.32 & .1422 & 2.353 \\
\hline
\end{tabular}

EM represents earnings management; DOWN represents directors' ownership; NEDOWN represents non-executive directors' ownership; EDOWN represents executive directors' ownership; CTEN represents CEO tenure; BSIZE represents board size; NEXD represents the proportion of non-executive directors on board; NLFSIZE represents the natural log of firm size; $L E V$ represents leverage; ROA represents return on assets; FAGE represents firm age. 


\subsection{Correlation Matrix}

Table 3 presents the correlations of the variables. The correlation pattern shows no multicollinearity issue. The average variance inflation factor is 1.21 and ranges from 1.03 to 1.43. The analysis shows a negative correlation and significance between EM and DOWN, which suggests that earnings management is significantly lower for firms more director ownership. The analysis also shows quite several significances between and among the variables, but overall, no problem of multicollinearity.

Table 3. Correlations

\begin{tabular}{|c|c|c|c|c|c|c|c|c|c|c|c|}
\hline & EM & DOWN & NEDOWN & EDOWN & CTEN & BSIZE & BCNEX & FSIZE & LEV & ROA & FAGE \\
\hline EM & 1.000 & & & & & & & & & & \\
\hline DOWN & $-0.116^{*}$ & 1.000 & & & & & & & & & \\
\hline NEDOWN & $0.086^{*}$ & $0.145^{*}$ & 1.000 & & & & & & & & \\
\hline EDOWN & 0.007 & -0.018 & $0.129^{*}$ & 1.000 & & & & & & & \\
\hline CTEN & $-0.110^{*}$ & -0.015 & $0.091^{*}$ & $0.070^{*}$ & 1.000 & & & & & & \\
\hline BSIZE & $-0.088^{*}$ & $-0.110^{*}$ & 0.044 & $-0.113^{*}$ & -0.005 & 1.000 & & & & & \\
\hline NEXD & -0.056 & $-0.165^{*}$ & -0.043 & $-0.104^{*}$ & 0.001 & $0.275^{\star}$ & 1.000 & & & & \\
\hline NLFSIZE & $-0.070^{*}$ & $-0.263^{*}$ & $-0.091^{*}$ & $-0.099^{*}$ & 0.015 & $0.388^{*}$ & -0.014 & 1.000 & & & \\
\hline LEV & 0.015 & $-0.121^{*}$ & 0.025 & $0.115^{\star}$ & $0.074^{*}$ & -0.031 & -0.031 & $0.209^{*}$ & 1.000 & & \\
\hline ROA & 0.048 & $-0.120^{*}$ & $0.238^{*}$ & 0.040 & -0.006 & 0.040 & 0.027 & $0.122^{*}$ & $-0.12^{*}$ & 1.000 & \\
\hline FAGE & 0.033 & $-0.327^{\star}$ & -0.019 & $0.098^{*}$ & $0.125^{*}$ & 0.001 & -0.009 & $0.093^{*}$ & $0.280^{*}$ & $0.097^{*}$ & 1.000 \\
\hline
\end{tabular}

Significance * is $5 \%$ or better. EM represents earnings management; $D O W N$ represents directors' ownership; NEDOWN represents non-executive directors' ownership; EDOWN represents executive directors' ownership; CTEN represents CEO tenure; BSIZE represents board size; NEXD represents the proportion of non-executive directors on board; NLFSIZE represents the natural log of firm size; $L E V$ represents leverage; $R O A$ represents return on assets; FAGE represents firm age.

\subsection{Regression Analysis}

Table 4 presents the regression results. We find that the proportion of shares owned by all directors DOWN is negatively associated with earnings management, -0.036 , significant at $5 \%$ level. This finding is consistent with prior studies and indicates a context wherein all board of directors could effectively restrain earnings management, hence lending support to hypothesis $1\left(H_{1}\right)$. We do not find evidence of curbing abnormal accruals when non-executive directors' ownership NEDOWN is concerned, though significant by encouraging bold choices. Hence, $H_{2}$ is not supported. This is contrary to expectation. The non-executive directors are expected to bring independence of opinion and objectivity of perspectives. A plausible explanation for this might be the low average interest of the non-executive directors in shareholding. The non-executive directors, like the shareholders, might act aggressively if their investments are at risk, or if their ownership increases. The coefficient for the executive directors EDOWN is not significant, so $\mathrm{H}_{3}$ is not supported.

All the explanatory variables are not significant, except CEO tenure (CTEN) that shows significance at the $10 \%$ level. 
Table 4. Regression analysis between earnings management (DV) and the explanatory variables (IVs)

\begin{tabular}{llll}
\hline VARIABLES & Fixed Effect & Random Effect & Random Effect (Robust) \\
\hline DOWN & $-0.036^{* *}$ & $-0.036^{* * *}$ & $-0.036^{* *}$ \\
NEDOWN & $(0.016)$ & $(0.011)$ & $(0.017)$ \\
& $0.056^{* * *}$ & $0.053^{* * *}$ & $(0.021)$ \\
EDOWN & $(0.015)$ & $(0.014)$ & -0.031 \\
& -0.034 & -0.031 & $(0.121)$ \\
CTEN & $(0.060)$ & $(0.056)$ & $-0.003^{* *}$ \\
& -0.001 & $-0.001^{* * *}$ & $(0.001)$ \\
BSIZE & $(0.001)$ & $(0.0004)$ & -0.0002 \\
& 0.0009 & -0.0002 & $(0.001)$ \\
NEXD & $(0.001)$ & $(0.001)$ & 0.008 \\
& 0.028 & 0.008 & $(0.018)$ \\
NLFSIZE & $(0.019)$ & $(0.016)$ & -0.003 \\
& -0.002 & -0.003 & $(0.002)$ \\
LEV & $(0.004)$ & $(0.002)$ & -0.003 \\
& -0.007 & -0.003 & $(0.013)$ \\
ROA & $(0.009)$ & $(0.009)$ & 0.005 \\
& 0.007 & 0.005 & $(0.010)$ \\
FAGE & $(0.007)$ & $(0.007)$ & -0.0001 \\
& $-0.001^{* *}$ & -0.0001 & $(0.0001)$ \\
Constant & $(0.001)$ & $(0.0002)$ & $0.115^{* * *}$ \\
Observations & $0.122^{* * *}$ & $0.115^{* * *}$ & $(0.027)$ \\
R-squared & $(0.032)$ & $(0.019)$ & 864 \\
P-value & 864 & 864 & 0.044 \\
Standard & 0.053 & 0.044 & 0.000 \\
\hline
\end{tabular}

Standard errors in parentheses ${ }^{* * *} p<0.01,{ }^{* *} p<0.05,{ }^{*} p<0.1$

$E M$ represents earnings management; DOWN represents directors' ownership; NEDOWN represents non-executive directors' ownership; EDOWN represents executive directors' ownership; CTEN represents CEO tenure; BSIZE represents board size; NEXD represents the proportion of non-executive directors on board; NLFSIZE represents the natural log of firm size; $L E V$ represents leverage; ROA represents return on assets; FAGE represents firm age.

\section{CONCLUSION}

This study examines the association between the board of directors' interest in shareholding and earnings management. Recent cases of financial reporting scandals have lent credence to the concern that the people whose responsibility is to prepare financial reports might get engaged in managing earnings. As prior studies have shown that a critical determinant of earnings management practice is corporate governance, we specifically examine corporate board shareholding as explained by the agency phenomenon. We partition between executive directors' ownership and non-executive directors' ownership to investigate which class of ownership exerts the most influence on earnings management. We find that non-executive directors' interests in shareholding are significantly associated with higher levels of earnings management. This implies that an increase in directors' shareholding is an incentive for aggressive opinion towards earnings, probably if the investment is at risk. We find no significance on executive directors' ownership. Overall, ownership by all directors combined significantly reduces managerial opportunism.

As in any study, this research is without some limitations. The study is drawn from the Nigerian regulatory context. So, the generalization of our findings should be taken with caution. Future studies could consider looking into whether the directors' shareholding is direct or indirect. An investigation into this specific might yield better insight on board dynamics. 


\section{REFERENCES}

Abbott, L. J., Daugherty, B., Parker, S., \& Peters, G. F. (2016). Internal audit quality and financial reporting quality: The joint importance of independence and competence. Journal of Accounting Research, 54(1), 3-40. http://doi.org/10.1111/1475-679X.12099

Alves, S. (2012). Ownership structure and earnings management: Evidence from Portugal. Australian Accounting Business and Finance Journal, 6(1), 57-74. http://doi.org/10.5539/ijbm.v7n15p88

Alzoubi, E. S. S. (2014). Board characteristics and financial reporting quality: Evidence from Jordan. Corporate Ownership and Control, 11(3), 8-29. http://doi.org/10.5296/ajfa.v4i1.1442

Dechow, P. M., Ge, W., \& Schrand, C. (2010). Understanding earnings quality: A review of the proxies, their determinants and their consequences. Journal of Accounting and Economics, 50(2-3), 344-401. http://doi.org/10.1016/j.jacceco.2010.09.001

Ebrahim, A. (2007). Earnings management and board activity: additional evidence. Review of Accounting and Finance, 6(1), 42-58. http://doi.org/10.1108/14757700710725458

Francis, B., Hasan, I., Park, J. C., \& Wu, Q. (2015). Gender differences in financial reporting decision-making: evidence from accounting conservatism. Contemporary Accounting Research, 32(3), 1285-1318. http://doi.org/10.2139/ssrn.2377312

Hooghiemstra, R., Hermes, N., Oxelheim, L., \& Randøy, T. (2019). Strangers on the board: The impact of board internationalization on earnings management of Nordic firms. International Business Review Journal, 28, 119-134. http://doi.org/10.2139/ssrn.2714428

Klein, A. (2002). Audit committee, the board of director characteristics, and earnings management. Journal of Accounting and Economics, 33(3), 375-400. http://doi.org/10.1016/S01654101(02)00059-9

Kothari, S. P., Leone, A. J., \& Wasley, C. E. (2005). Performance matched discretionary accrual measures. Journal of Accounting and Economics, 39(1), 163-197. http://doi.org/https://doi.org/10.1016/j.jacceco.2004.11.002

O'Callaghan, S., Ashton, J., \& Hodgkinson, L. (2018). Earnings management and managerial ownership in private firms. Journal of Applied Accounting Research, 19(4), 648-668. http://doi.org/doi.org/10.1108/JAAR-11-2017-0124

Peasnell, K. V., Pope, P. F., \& Young, S. (2005). Board monitoring and earnings management: Do outside directors influence abnormal accruals? Journal of Business Finance and Accounting, 32(7-8), 1311-1346. http://doi.org/10.1111/j.0306-686X.2005.00630.x

Ran, G., Fang, Q., Luo, S., \& Chan, K. C. (2015). Supervisory board characteristics and accounting information quality: Evidence from China. International Review of Economics \& Finance, 37, 18-32. http://doi.org/10.1016/j.iref.2014.10.011

Sharon, P. K. (2009). Earnings quality and ownership structure: The role of private equity sponsors. The Accounting Review, 84(3), 623-658. http://doi.org/10.2307/27784189

Teshima, N., \& Shuto, A. (2008). Managerial ownership and earnings management: Theory and empirical evidence from Japan. Journal of International Financial Management and Accounting, 19(2), 107-132.

Tessema, A., Kim, M. S., \& Dandu, J. (2018). The impact of ownership structure on earnings quality: The case of South Korea. International Journal of Disclosure and Governance, 15(3), 129 141. http://doi.org/10.1057/s41310-018-0039-x

Ujunwa, A., Okoyeuzu, C., \& Nwakoby, I. (2012). Corporate board diversity and firm performance: Evidence from Nigeria. Revista de Management Comparat International, 13(4), 605-620. Retrieved from https://search.proquest.com/docview/1355867187?pq-origsite=gscholar

Vafeas, N. (2005). Audit committees, boards, and the quality of reported earnings. Contemporary Accounting Research, 22(4), 1093-1122. http://doi.org/10.1506/1QYN-2RFQ-FKYX-XP84

Waweru, N. M., \& Prot, N. P. (2018). Corporate governance compliance and accrual earnings management in eastern Africa: Evidence from Kenya and Tanzania. Managerial Auditing Journal, 33(2), 171-191. http://doi.org/http://dx.doi.org/10.1108/MRR-09-2015-0216 